\title{
A EXIGIBILIDADE JUDICIAL DO DIREITO FUNDAMENTAL À EDUCAÇÃO NA CONSTITUIÇÃO DE 1988
}

\author{
ISABELA BENTES DE LIMA*
}

\begin{abstract}
RESUMO: O presente artigo tem como objeto analisar a efetividade do direito à educação na Constituição de 1988, a partir da análise de duas decisões judiciais proferidas em dois casos concretos que foram levados ao Supremo Tribunal Federal, fenômeno denominado por maior parte da doutrina de "judicialização de políticas públicas", trata-se do caso Santo André/SP e do caso Queimados/RJ. As referidas decisões são apreciadas conforme os princípios e valores constitucionais, a partir do postulado de que o Estado Social e Democrático de Direito é protetor dos direitos sociais. Foi relevante considerar que os argumentos sobre o mínimo existencial e a escassez de recursos devem ser apreciados com o máximo de cuidado, tendo sido concluído que as demandas coletivas de satisfação do direito à educação são prioritárias em relação as demandas individuais, embora ambas sejam exigíveis.
\end{abstract}

PALAVRAS-CHAVE: Direitos Fundamentais; Direito à Educação; Estado Social e Democrático de Direito; Poder Judiciário; Política Pública.

ABSTRACT: The current article aims to examine the effectiveness of the right to education in Brazilian 1988 Constitution, through the analyzes of the two judgments of Supreme Court, phenomenon called by the most of doctrine as "judicialization of public policies”, is the case Santo André / SP and case Queimados/ RJ. This judgments are criticized according to the principles and values that guiding the Brazilian Constitution, based on referential that the Social and Democratic State of Rights is protector of the social rights. Was relevant consider carefully the ideias of "existential minimum", and the scarcity of resources, and was concluded that the collective demands have a priority satisfaction than the individual demands, despite both of them are required.

KEYWORDS: Fundamental Rights; Right to education; Democratic and Social State of Rights; Judiciary; Public Policy.

SUMÁRIO: 1. O Supremo Tribunal Federal e o Direito Fundamental à Educação; 1.1. Os argumentos do Ministro Relator Celso de Mello no caso Santo André/SP; 1.2. Os argumentos do Ministro Relator Gilmar Mendes no caso do Município de Queimados/RJ; 1.3. Comentários sobre as Decisões; Considerações Finais; Referências.

SUMMARY: 1. The Supreme Court and the Right to Education; 1.1. The arguments of the judge Celso de Mello in the case Santo André/SP; 1.2 The arguments of the judge Gilmar Mendes in the case Queimados/RJ; 1.3. Comentaries about this Decisions; Conclusion; References.

Artigo recebido em 4.06.2010 e aprovado para publicação pelo Conselho Editorial em 6.01.2011.

* Advogada e Mestra em Direitos Humanos pela Universidade Federal do Pará. 


\section{O SUPREMO TRIBUNAL FEDERAL E O DIREITO FUNDAMENTAL}

À EDUCAÇÃO

A temática que envolve a eficácia dos direitos sociais já há algum tempo vem ganhando maior espaço nas discussões acadêmicas, em razão de sua extrema importância dentro do contexto social. A sociedade brasileira, manchada pela desigualdade, pobreza, analfabetismo, desemprego, deficiências nos serviços públicos de saúde, caos da Previdência Social, entre outros, reclama por soluções a essas celeumas, requerendo a presença de um Estado que, cada vez mais forte, seja capaz de sanar tais máculas.

São problemas que vêm acompanhando a evolução das Constituições no Brasil, indicando que o papel do Estado é fundamental para implementar mudanças na área social, sobretudo no que diz respeito ao direito à educação. Com a Constituição de 1988, atingimos o mais alto patamar de proteção aos direitos sociais, principalmente em relação ao direito à educação, embora este tenha sido objeto da salvaguarda constitucional desde a Constituição Imperial de 1824.

A discussão em torno do papel da educação num Estado Social e Democrático de Direito, como claramente se assumiu o Brasil na Constituição de 1988, e da efetividade deste direito por meio da via judicial, consiste no objetivo deste artigo, através de análise de como este tema tem sido tratado pela jurisprudência do Supremo Tribunal Federal. Pois, a educação é verdadeira arma de emancipação social, responsável por transferir indivíduos de uma situação social desfavorável para outra com mais qualidade de vida, por criar cidadãos que se comportem como sujeitos democráticos que se importam com a construção de uma sociedade atenta aos direitos humanos, ao respeito e à tolerância. A educação, pressuposto do exercício de liberdades, contribuindo para a promoção da igualdade, é um assunto essencial a ser trazido ao lume, porque é através dela que serão alcançados os objetivos constitucionalmente delineados.

Em pesquisa jurisprudencial realizada no site do Supremo Tribunal Federal, tendo como referência o período de tempo compreendido entre 1988 e 2008, ou seja, nos vinte anos da Constituição da República, importa destacar as decisões proferidas no Agravo Regimental no Recurso Extraordinário 410715-5, o famoso caso de Santo André/SP, que trata da falta de vagas em creche para crianças. E destaque-se também a decisão proferida no pedido de suspensão de tutela antecipada pelo Estado do Rio de Janeiro de n. 241-7, em que foi requerido por este a prorrogação do prazo para a eficácia da decisão que determinou o ingresso de professores na rede estadual de ensino do Município de Queimados. São estas duas decisões que serão analisadas por serem as que demonstram o posicionamento que vem sendo proferido nas demandas de exigibilidade do direito fundamental à educação pelo Supremo Tribunal Federal, à luz dos dispositivos constitucionais sobre a temática, argumentos doutrinários sobre o tema e conceitos como mínimo existencial, reserva do possível, entre outros.

1.1 Os argumentos do Ministro Relator Celso de Mello no caso Santo André/SP

O caso Santo André iniciou quando o Ministério Público do Estado de São Paulo interpôs ação civil pública em desfavor do Município de Santo André, em virtude da 
falta de vagas em creche e pré-escola para crianças. O referido processo chegou ao STF através da propositura de recurso extraordinário (n. 410.715-5) pelo Ministério Público do Estado de São Paulo, que foi conhecido e provido. Em razão disso, o Município referido apresentou recurso de agravo, cujo provimento foi negado por unanimidade pelos ministros.

O voto do ministro relator Celso de Mello inicia com a afirmação de que o recorrente não possui razão jurídica, pois considera que a decisão agravada estava em conformidade com as normas da Constituição, declarando que se numa extremidade existe o direito público subjetivo à educação, em outra há o dever jurídico-social em proporcionar para as crianças de zero a seis anos de idade o efetivo acesso e atendimento em creches e unidades pré-escola. ${ }^{1}$

$\mathrm{O}$ ministro reconhece o direito à educação como um direito social que exige a prestação positiva dos Poderes Públicos ("facere") para que todos tenham acesso pleno ao sistema educacional. Como direito de segunda dimensão que é, o direito à educação é apresentado ao lado de uma exigência de solidariedade social e da dignidade humana e como valor que contamina todo o ordenamento político.

De forma mais específica, o direito à educação infantil é colocado como de alto significado social e de irrecusável valor constitucional, e, embora o ministro não tenha demonstrado o que significam essas designações, se refere ao dever do Estado em prover esse direito, uma vez que é o ente idôneo para fornecer a garantia de atendimento em creche e pré-escola de modo a cumprir os mandamentos da Constituição (artigo 208, inciso IV).

Para o ministro, o constituinte traçou programa a ser concretizado através de políticas públicas, com o objetivo de corrigir a exclusão social presente no sistema de ensino. Ou seja, agir de forma contrária implica em incorrer em inconstitucional omissão.

O julgamento da Arguição de Descumprimento de Preceito Fundamental n. 45 (ADPF 45), cujo relator também foi o ministro Celso de Mello, foi relembrada no voto em estudo. O ministro ressaltou a dimensão política da jurisdição do STF e o mister da Suprema Corte em efetivar os direitos de segunda dimensão para manter a integridade e a eficácia da Constituição, condenando a inconstitucionalidade que significa a inércia do Poder Público em não realizar as prestações positivas que requer tais direitos. O ministro admite não ser competência ordinária do STF a elaboração e implementação de políticas públicas, pois considera que este é um trabalho para ser desempenhado pelo Poder Legislativo e pelo Poder Executivo. No entanto, afirma que em caráter de excepcionalidade pode o Poder Judiciário fazer uso dessa competência quando a eficácia e a integridade de direitos individuais e/ou coletivos ficarem em vias de não concretização.

De modo a não esquecer os gastos com as prestações positivas que requer a concretização dos direitos sociais, o ministro relator do voto menciona o princípio da reserva do possível como obstáculo a ser enfrentado para a imediata efetivação

${ }^{1}$ A decisão em comento é de 22 de novembro de 2005. Nessa ocasião a Constituição de 1988 ainda não havia sido modificada pela Emenda Constitucional n. 53 que modificou dispositivo, qual seja, o inciso 208, inciso IV, passando a educação infantil ser prestada para crianças de zero a cinco anos. 
daqueles direitos. É que considera o relator que, diante de um justo motivo objetivamente aferível, não há como exigir do Poder Público o cumprimento dos deveres constitucionalmente delineados. Por outro lado, a Administração não pode criar propositadamente embaraços que impeçam a efetivação dos direitos sociais:

A partir de indevida manipulação de sua atividade financeira e/ou político-administrativa - o ilegítimo, arbitrário e censurável propósito de fraudar, de frustrar e de inviabilizar o estabelecimento e a preservação, em favor da pessoa e dos cidadãos, de condições materiais mínimas de existência. ${ }^{2}$

A discricionariedade da Administração Pública quanto à efetivação do direito à educação foi um dos temas abordados pelo ministro. O ministro aduz que a educação infantil, enquanto direito de prestação positiva que se subsume ao conceito de liberdade real ou concreta, tem como respaldo norma constitucional cuja densidade não autoriza que o Poder Público (no caso em tela o Município de Santo André) usufrua de margem ampla de discricionariedade, pois alega que a mera conveniência e oportunidade não podem servir como argumento para não realizar políticas públicas assinaladas pela Constituição.

A disposição constitucional que determina que a educação infantil e fundamental seja prioridade do Município consiste em mandato constitucional juridicamente vinculante e que consiste em fator de limitação da discricionariedade políticoadministrativa.

Ou seja, para o ministro, a discricionariedade do Estado não pode prejudicar a eficácia do direito à educação, cujo caráter é de cunho social, ressaltando a supremacia da Constituição em detrimento da liberdade do administrador público quando esta garante a concretização de direitos.

E é a fundamentalidade do direito à educação que permite que o Poder Judiciário adote medidas que torne real esse direito. O ministro reconhece a razão jurídica do Ministério Público do Estado de São Paulo, afirmando que as deficiências da administração da coisa pública, geradas pela má preparação dos gestores em lidar com os cofres públicos, pela ausência de amplitude de uma visão política em tratar de temas de extrema importância social, pelo desrespeito às normas constitucionais, não podem prejudicar o exercício do dever do Estado em promover o direito à educação, que, no caso concreto, se materializava com o fornecimento de creches públicas e de ensino pré-primário para as crianças de zero a seis anos de idade.

\subsection{Os argumentos do Ministro Relator Gilmar Mendes no caso do Município de Queimados/RJ}

O Ministério Público do Estado do Rio de Janeiro (MP/RJ) propôs ação civil pública em desfavor do Estado do Rio de Janeiro em razão da ausência ou insuficiência do número de professores na rede pública estadual de ensino no Município de Queimados. O MP/RJ pediu antecipação de tutela concedida pelo Juizado da família, da infância, da juventude e do idoso da comarca daquele município para que o Estado

\footnotetext{
${ }^{2}$ Trecho destacado do voto do Ministro Relator Celso de Mello.
} 
do Rio de Janeiro preenchesse o quadro de professores no prazo de 10 dias sob pena de pagamento de multa diária no valor de vinte mil reais.

O Estado do Rio de Janeiro interpôs agravo de instrumento, com pedido de suspensão de tutela antecipada, para prorrogar o prazo de eficácia da decisão para o início do ano letivo de 2008, cujo efeito suspensivo foi negado pelo desembargador relator do Tribunal de Justiça daquele Estado, o magistrado Carlos Eduardo Fonseca Passos. Porém, a decisão da segunda câmara cível julgou o mérito do recurso concedendo a prorrogação do prazo. O Estado do Rio de Janeiro interpôs recurso extraordinário que até então estava sujeito ainda ao juízo de admissibilidade.

O relator da decisão em estudo foi o ministro Gilmar Mendes que na ocasião já atuava como presidente do STF, cujo voto será aqui analisado. A ação civil pública trazia informações acerca do prejuízo causado pela insuficiência de professores da rede estadual de ensino no Município de Queimados apurada em inquérito civil (n. 04/05) consistindo em problemática que se alastrou por toda a cidade e não isoladamente.

Trata-se de apreciação do pedido de suspensão de decisão judicial, mas o ministro Gilmar Mendes faz uso da prerrogativa de poder proferir juízo mínimo de delibação acerca das questões jurídicas constantes na ação conforme precedentes jurisprudenciais da Suprema Corte.

Primeiramente, o ministro revela o confronto entre o princípio da separação de poderes de um lado, versus a proteção constitucional dos direitos das crianças e dos adolescentes e o dever do Estado em prestar serviços de ensino com gratuidade e qualidade de outro. O direito à educação das crianças e dos adolescentes (artigo 227 da $\mathrm{CR} / 88$ ) ao ensino fundamental é colocado pelo ministro como direito público subjetivo, que acarreta em responsabilidade da autoridade competente, e que deve ter absoluta prioridade conforme determinação da Constituição.

O aspecto objetivo do direito à educação é apresentado como o dever do Estado em construir condições para seu usufruto. Na ótica do ministro, além de proibição de intervenção no exercício dos direitos fundamentais, há o postulado de proteção a eles: "não apenas uma proibição de excesso (Übermassverbot), mas também uma proibição de proteção insuficiente (Üntermassverbot)”’3. A dimensão objetiva cria, também, o dever de criar órgãos públicos e procedimentos específicos para a plena efetivação do direito à educação por parte do Estado.

Quanto à separação dos poderes, aduz o ministro que não houve lesão à ordem pública, pois para ele há um modo constitucionalmente adequado de entender o citado princípio: através da combinação entre a teoria da constituição e a experiência constitucional, atividade que requer temperamentos e reparos conforme a realidade brasileira. Segundo Gilmar Mendes:

A alegação de violação à separação dos poderes não justifica a inércia do Poder executivo estadual do Rio de janeiro em cumprir seu dever constitucional de garantia do direito à educação e dos direitos da criança e do adolescente, com a absoluta prioridade reclamada no texto constitucional.

\footnotetext{
${ }^{3}$ Trecho retirado do voto do Ministro Relator Gilmar Mendes.
} 
Quanto à alegação de grave lesão à economia pública, o ministro considera igualmente inadmissível, pois considera que a Constituição e o Estatuto da Criança e do Adolescente expressamente designaram prioridade para a elaboração e execução de políticas públicas voltadas para o ensino fundamental.

Dois documentos internacionais são mencionados para exaltar a importância do direito à educação: o Pacto Internacional sobre Direitos Econômicos, Sociais e Culturais, que obriga os Estados signatários a garantir o pleno exercício desse direito, e a Declaração Mundial sobre Educação para todos, em que o Brasil firmou compromisso em criar Plano Nacional de Educação. O ministro afirma que seu voto se encontra em consonância com os demais precedentes da Corte citando-os.

O respeito ao princípio da legalidade foi lembrado no voto na afirmação de que o Poder Executivo não pode fazer uso da discricionariedade em criar ou não as políticas públicas que já foram determinadas pela própria Constituição. As dotações orçamentárias, por sua vez, devem ser destinadas para a educação antes que sejam alocadas para outras áreas. Sendo assim, a reserva do possível dever ser usada com cautela, afirma o ministro, pois não pode ser utilizada levianamente como forma de justificar uma omissão estatal.

Por fim, o ministro rejeita a existência de usurpação das funções do Poder Judiciário perante as do Poder Executivo, pois avalia que o que há no caso em estudo é tão somente decisão judicial estabelece que se cumpra dever constitucional. O único ponto que discorda da decisão impugnada é quanto à fixação da multa diária no valor de vinte mil reais, medida considerada como ônus excessivo a ser suportado pelo Poder Público, e, conseqüentemente, pela sociedade prejudicando dotações orçamentárias mais importantes.

\subsection{Comentários sobre as decisões}

Em se tratando da exigibilidade judicial do direito à educação, verificou-se que há uma incidência muito menor dessas demandas no Supremo Tribunal Federal em comparação com o direito à saúde.

O primeiro ponto a ser destacado, então, é que a discussão sobre a efetividade do direito à educação tem sido uma temática ainda timidamente abordada pela instância suprema. Esta circunstância, de certa forma, comprometeu a análise pretendida nesse trabalho, uma vez que a citada escassez de decisões torna a abordagem do tema proposto um pouco mais distante da realidade prática do STF, dificultando a associação entre teoria e prática.

Apesar de tais considerações, a respeito da carência de decisões que encarem a exigibilidade judicial, é importante ressaltar que tanto o caso Santo André/SP como caso Queimados/RJ, são apresentados como acontecimentos emblemáticos que indicam o atual posicionamento do STF e a forma como ele tende a ponderar questões sobre o direito fundamental à educação.

A escassez de decisões judiciais no tema da educação também foi identificada por José Reinaldo de Lima Lopes em algumas pesquisas jurisprudenciais realizadas por ele no Superior Tribunal de Justiça e no Tribunal de Justiça de São Paulo. ${ }^{4}$

${ }^{4}$ LOPES, José Reinaldo de Lima. Direitos sociais: teoria e prática. São Paulo: Método, 2006. p. 124. 
A pesquisa junto ao site do Supremo Tribunal Federal permitiu que fosse atingida a mesma conclusão, bem como foi identificado que o tema da educação ainda se encontra apartado dos estudos doutrinários em relação aos outros direitos fundamentais. ${ }^{5}$ O direito à saúde é o direito social que mais vem adquirindo espaço de discussão acadêmica seguido de forma ainda acanhada pelo direito à educação.

Para o posicionamento da questão, importante identificar que os dois casos iniciaram por meio de ações civis públicas interpostas pelo Ministério Público do Estado de São Paulo (no caso Santo André) e pelo Ministério Público do Estado do Rio de Janeiro (no caso do Município de Queimados), que figuram, portanto, na lide como autores das citadas ações. Os réus são o Estado de São Paulo e o Estado do Rio de Janeiro. São ações cujo objeto era a proteção de interesses coletivos relacionados ao acesso à educação infantil e fundamental, respectivamente.

Observa-se que, embora a relação processual tenha se construído de forma bilateral, autor de um lado, réu de outro, as questões trazidas nas ações civis públicas guardam relação com a organização social. Pois, envolve uma coletividade de interesses: de crianças e adolescentes em terem acesso à educação e de pais e responsáveis que querem ver seus filhos na escola. São litígios a serem observados de forma plurilateral ${ }^{6}$, pois seus resultados atingem toda sociedade, ainda mais porque envolvem o uso de recursos públicos no gasto com o direito à educação.

As demandas de cunho plurilateral são aquelas em que giram em torno de um objeto indivisível ou que se encontra indivisível, ou seja, as relações dos sujeitos que tem interesse no referido objeto interferem "em cada um diante de todos e todos diante de cada um". 7 Significa dizer que uma decisão judicial que venha a ser proferida diante de litígio de caráter plurilateral irá atingir pessoas que não estiveram atuando como sujeito processual. Questões que envolvem discussões sobre bens indivisíveis, plurilaterais podem ser levadas ao Judiciário, mas esse novo enfoque multifacetado há que fazer parte das deliberações. ${ }^{8}$

A educação pode ser considerada um bem indivisível que, nos termos do Código Civil, significa ser um bem que não pode ser fracionado em partes iguais sem que as qualidades essenciais sejam afetadas, desvalorizadas ou que haja algum prejuízo. ${ }^{9}$

\footnotetext{
${ }^{5}$ Do mesmo modo constatou Gina Vidal Marcílio Pompeu a pequena quantidade de processos que envolvia pedidos de acesso à educação em pesquisa desenvolvida no Estado do Ceará, que no total de cento e oitenta e quatro municípios apenas em dois deles foram identificadas demandas de judicialização do direito à educação. As informações auferidas pelos diretores de secretaria dos fóruns é que as denúncias, reivindicações e problemas indicados pela população não chegam à via judicial em razão da atuação do Ministério Público que fornecem orientações, realizam conciliações e fazem termos de ajustamento de conduta. As conclusões atingidas foram de que a educação ainda não consiste em temática que faça parte do dia a dia do Poder Judiciário, e que este possui dificuldade em se posicionar diante das demandas por acesso à educação. Por esta razão, aquela autora teceu críticas à atuação tanto do Ministério Público quanto do Poder Judiciário, afirmando que eles ocupam-se muito mais com as querelas individuais. (POMPEU, Gina Vidal Marcílio. Direito à educação: controle social e exigibilidade judicial. Rio - São Paulo - Fortaleza: ABC editora, 2005. p. 220 e 223).

${ }^{6}$ LOPES, op. cit. p.128.

${ }^{7}$ Ibidem p. 171.

${ }^{8}$ Ibidem p. 172

${ }^{9}$ Artigo 87 do Código Civil dispõe que "bens divisíveis são os que podem fracionar sem alteração na sua substância, diminuição considerável de valor, ou prejuízo do uso a que se destinam.”
} 
Embora exista o exercício individual do direito à educação, a sua prestação por parte do Estado é realizada coletivamente por meio de oferta de vagas em escolas, por exemplo, e, de um modo geral, através de políticas públicas. São sempre prestações voltadas para atingir o todo e não a soma de indivíduos particularmente. Afinal, uma sala de aula não é criada em função da matrícula de um aluno e sim de vários, assim como uma escola não existe somente por causa de um estudante. E a fundação de instituições de ensino é feita em virtude de uma vontade geral de se ter acesso à educação e, consequentemente, promover a formação de pessoas humanas em diversos aspectos.

Levando em conta tais argumentações, examina-se que tanto o caso de Santo André/SP, quanto o caso de Queimados/RJ, dizem respeito a demandas que trazem como pano de fundo questões de justiça distributiva, pois envolvem o acesso a um bem comum, que nos casos concretos referidos são, de um modo geral, o acesso à educação.

No primeiro caso, onde se requereu aumento de número de vagas em creche obrigando o Município de Santo André/SP a matricular crianças que estivessem fora do sistema de ensino. No segundo caso, onde foi requerido o preenchimento do quadro de professores na rede pública de ensino estadual naquele Município, para que as crianças e adolescentes não ficassem mais sem aulas.

A noção de bem comum não se confunde com o conjunto de vontades de vários indivíduos e sim atinge um interesse que é comum a todos os membros da coletividade, objetivando a distribuição igual de coisas comuns, de coisas produzidas em comum, de autoridade e poder e de incentivos a talentos individuais socialmente relevantes. Nesse sentido, José Reinaldo de Lima Lopes chega a um ponto interessante ao afirmar que problemas de justiça distributiva têm atingido o Judiciário, pois tal assertiva se comprova na análise dos casos em destaque, que se reportam sobre o acesso dos pobres ao fundo econômico comum. ${ }^{10}$

Ambos os casos se referem ao acesso ao ensino público, o que faz presumir pela hipossuficiência financeira do corpo de alunos que necessitam dos serviços públicos de educação. E isso se confirma com o fato de que o Ministério Público, no exercício de suas atribuições constitucionais, foi a juízo defender interesses coletivos de crianças e adolescentes em exercer o direito à educação por meio da escola pública.

A justiça distributiva objetiva a repartição igual ou proporcional de coisas comuns (aquelas não criadas por ninguém como céu e a terra, por exemplo); coisas produzidas em comum, mas que não pertencem particularmente a nenhum indivíduo (como a língua e a cultura, por exemplo); autoridade e poder (salvaguardados os direitos e deveres decorrentes) e incentivos a talentos individuais socialmente relevantes e queridos. A distribuição desse amontoado de coisas comuns é que conduz ao acesso ao bem comum pretendido pela justiça distributiva colocando os indivíduos em condições para promover a realização pessoal. ${ }^{11}$

A educação como bem coletivo e indivisível se encaixa nas coisas que deve chegar a todos indistintamente e de forma igual. As demandas apreciadas constituem-se em

\footnotetext{
${ }^{10}$ Ibidem. p. 126.
}

${ }^{11}$ Ibidem. p. 128.

Direitos Fundamentals E JUSTIÇA N 13 - OUt./DEZ. 2010 
tema que envolve a distribuição de oportunidades de aprender a língua, a cultura, a história, os diversos ramos da ciência, entre outros. E, como o centro das discussões é sobre o ensino público, o caso Santo André/SP e o caso Queimados/RJ se referem à participação dos pobres no fundo social comum.

Em ambas as decisões, o STF se pronunciou de modo favorável à efetividade do direito à educação, pronunciando-se em favor da concessão dos pedidos feitos pelo Ministério Público. É por causa das razões ora aventadas que a Suprema Corte decidiu os casos de forma correta, pois são ações coletivas que visam à repartição do bem comum que é o acesso à educação.

Uma vez consideradas acertadas as decisões do STF no caso Santo André/SP e no caso Queimados/RJ, pois foi considerado que as ações civis públicas cumpriram com o intento da justiça distributiva, cumpre relembrar que a Constituição de 1988 declarou que o acesso ao ensino obrigatório e gratuito (fundamental) é um direito público subjetivo (artigo 208, $\S 1^{\circ}$ ). E que em caso de falta de oferta ou sendo esta irregular, à autoridade competente é imputada responsabilidade (artigo 208, $\S 2^{\circ}$ ). ${ }^{12}$ A Lei de Diretrizes e Bases da Educação reafirma que o acesso ao ensino fundamental se trata de direito público e subjetivo, arrolando, ainda, aqueles que têm legitimidade para exigir judicialmente a efetividade desta norma perante o Poder Público.

Será que o fato de a Constituição ter designado expressamente que o acesso ao direito fundamental é direito público subjetivo retira essa subjetividade dos outros direitos previstos em normas constitucionais referentes à educação ${ }^{13}$

Em outras palavras, a satisfação coletiva e a individual do direito à educação são compatíveis? A questão se apresenta oportunamente, uma vez que a titularidade do direito à educação é coletiva e seu objeto são as políticas públicas. ${ }^{14}$

A análise da exigibilidade do direito à educação passa pela reflexão sobre as questões acima aludidas, principalmente no que se refere à relação entre o direito subjetivo público ao ensino fundamental e as outras normas inseridas no capítulo constitucional sobre a educação. Pois, parte da doutrina já se manifestou afirmando que o ensino fundamental corresponde ao mínimo de garantia fornecida pela Constituição quanto ao direito à educação, deixando bastante óbvia a sua exigibilidade perante os órgãos do Poder Judiciário, já que a falta ou oferta irregular deste ensino acarreta a responsabilidade da autoridade competente.

É o caso de Maliska, quando afirma que "a garantia do ensino fundamental obrigatório é o mínimo em termos de educação”. ${ }^{15}$ A esse respeito, aduz Emerson Garcia que "o direito à educação fundamental foi considerado uma parcela indissociável de uma existência digna de tantos quantos vivam em território brasileiro,

${ }^{12} \mathrm{O}$ Estatuto da Criança e do Adolescente repete a redação constitucional no artigo 54, parágrafos $1^{\circ}$ e $2^{\circ}$.

${ }^{13}$ Clarice Seixas Duarte elabora tal questionamento para nortear sua investigação sobre o direito público subjetivo ao ensino fundamental. (DUARTE, Clarice Seixas. O direito público subjetivo ao ensino fundamental na constituição de 1988. Faculdade de Direito da USP. São Paulo: 2003. p. 207)

${ }^{14}$ DUARTE, op. cit. p. 206 e 208.

${ }^{15}$ MALISKA, Marcus Augusto. Direito à Educação e a Constituição. Porto Alegre: Fabris, 2001. p. 222. 
integrando o que se convencionou chamar de mínimo existencial”. ${ }^{16}$

No entanto, como dizer que o ensino fundamental consiste em mínimo em se tratando da prestação do direito à educação se a educação infantil o precede obrigatoriamente? Trata-se, de fato, do mínimo existencial do direito à educação?

No desenvolvimento do estudo do mínimo existencial, Ricardo Lobo Torres se apropria da teoria do status, para compreender o conteúdo daquele instituto. O referido autor atribui ao status negativus libertatis uma condição de exercício da liberdade de ação ou omissão que não pode sofrer cerceamento pelo Estado, a autodeterminação do indivíduo, gerando imunidade ao indivíduo e impedimento ao Estado de exercer seu poder tributário. É o que ocorre nas imunidades do imposto de renda para pessoas de baixa renda, bem como na gratuidade de ações como habeas corpus, ação popular e habeas data. ${ }^{17} \mathrm{O}$ status positivus libertatis, por sua vez, confere ao Estado a prestação de serviços públicos específicos e divisíveis direcionados à manutenção da liberdade da pessoa através da atividade da polícia, das forças armadas e da diplomacia. E por fim, o status positivus socialis consiste nas prestações estatais referentes à guarda dos direitos econômicos e sociais, sujeitos aos limites da escassez de recursos, da conjuntura econômica, e de legislação concessiva, a serem implementados através de políticas públicas. ${ }^{18}$

Na ótica de Ricardo Lobo Torres, os direitos sociais não possuem efetividade obrigatória, pois carecem da fundamentalidade peculiar dos direitos fundamentais, não fazem parte do rol de deveres do Estado e se encontram no âmbito da implementação da justiça social. Então, a teoria do status, concebida na forma descrita, desconsidera que os direitos sociais constituem direito público subjetivo da pessoa. ${ }^{19}$

Desse modo, o mínimo existencial se insere no espaço em que o Estado está obrigado a agir funcionando como forma de propiciar as condições de liberdade e a personalidade do cidadão, de modo algum se referindo a qualquer concepção de justiça. ${ }^{20}$ Sobre o assunto Ricardo Lobo Torres aduz que:

Carece o mínimo existencial de conteúdo específico. Abrange qualquer direito, ainda que originalmente não-fundamental (direito à saúde, à alimentação, etc.), considerado em sua dimensão essencial e inalienável. Não é mensurável, por envolver mais os aspectos de qualidade que de quantidade, o que torna difícil estremá-lo em sua região periférica, do máximo de utilidade (maximum welfare, Nutzenmaximierung), que é princípio ligado à ideia de justiça e de redistribuição da riqueza social. ${ }^{21}$

\footnotetext{
${ }^{16}$ GARCIA, Emerson. O Direito à educação e suas perspectivas de efetividade In: A efetividade dos direitos sociais. Coordenador: Emerson Garcia. Rio de Janeiro: Editora Lumen Juris, 2004. p. 169.

${ }^{17}$ TORRES, Ricardo Lobo. Os direitos humanos e a tributação: imunidades e isonomia. Rio de Janeiro: Renovar, 1995, p. 139-157 passim.

${ }^{18}$ Ibidem. p. 139.

${ }^{19}$ Ibidem. p. 133.

${ }^{20}$ Ibidem. p. 153.

${ }^{21}$ Ibidem. p. 128.
}

Direitos Fundamentals $\mathcal{E}$ Justiça N' 13 - OUt./Dez. 2010 
Para Ricardo Lobo Torres, o mínimo existencial se confunde com o conceito de direitos fundamentais sociais e se diferencia da concepção de direitos sociais. Essa demarcação é essencial para estabelecer o espaço em que incide a obrigatoriedade em prever e implementar prestações públicas. ${ }^{22}$ Destaca aquele autor que se por um lado o mínimo existencial não necessita de lei ordinária e não se sujeita às limitações da reserva do possível, uma vez que se encontra no âmbito da obrigatoriedade do Estado de agir, de outro lado os direitos econômicos e sociais carecem completamente de concessão do legislador. ${ }^{23}$ Sendo assim, as prestações referentes ao mínimo existencial estariam autorizadas para serem concedidas pelo Poder Judiciário, uma vez que não dependem da discricionariedade do Administrador Público. Um dos problemas apontado pelo autor é quando há aproximação dos direitos sociais com o mínimo existencial. Como exemplo cita as prestações de saúde após as emendas constitucionais como a de número 29/2000, que assegurou recursos mínimos para o financiamento das ações e serviços públicos de saúde. Então, aduz o autor que, diante de uma demanda que pleiteie a aplicação deste tipo de norma, a implementação da política pública pelo Judiciário se torna obrigatória. ${ }^{24}$

Com relação às prestações positivas de proteção ao mínimo existencial, diz o referido autor:

O judiciário pode determinar a entrega das prestações positivas, eis que tais direitos fundamentais não se encontram sob a discricionariedade da Administração ou do Legislativo, mas se compreendem nas garantias institucionais da liberdade, na estrutura de serviços públicos essenciais e na organização de estabelecimentos públicos (hospitais, clínicas, escolas primárias, etc). ${ }^{25}$

Analisando o direito público subjetivo ao ensino fundamental, se este seria o mínimo existencial da educação, Clarice Seixas Duarte parte da presunção de que os direitos sociais têm caráter subjetivo, embora sejam de natureza social, e a sua exigibilidade é específica em razão da natureza diferenciada desses direitos. A peculiaridade a que se refere é justamente quanto ao objeto dos direitos sociais que são as políticas públicas cujos titulares são grupos sociais em situação de vulnerabilidade econômica ou política. ${ }^{26}$

Outro pressuposto de que a citada autora parte é de que embora os direitos sociais possuam sua dimensão subjetiva, a satisfação somente dessa esfera não é suficiente para atingir a complexidade desses direitos, pois direitos como a educação e a saúde precisam de esquemas políticos que se encaixem numa realidade de atendimento coletivo, o que não exclui o atendimento individual na exigibilidade de tais direitos.

22 TORRES, Ricardo Lobo. O mínimo existencial, os direitos sociais e os desafios de natureza orçamentária. In: Direitos Fundamentais - orçamento e "reserva do possível”. Organizadores: Ingo Wolfgangg Sarlet, Luciano Benetti Timm. Porto Alegre: Livraria do Advogado Editora, 2008. p. 80.

${ }^{23}$ Ibidem. p. 83.

${ }^{24}$ Ibidem. p. 82

${ }^{25}$ Ibidem. p. 81.

${ }^{26}$ DUARTE, Clarice Seixas. O Direito Público Subjetivo ao Ensino Fundamental na Constituição de 1988. Faculdade de direito da USP. São Paulo: 2003. p. 205. 
Considera, também, que o Estado Social de Direito traz consigo mecanismos de controle das prestações positivas, isto é, de políticas públicas a serem monitoradas pela sociedade, pois não são somente os indivíduos que demandam cumprimento de direitos, mas também grupos de indivíduos. E o direito público subjetivo consiste em instrumento jurídico de controle da atuação estatal. ${ }^{27}$

Clarice Seixas Duarte argumenta que se num Estado Liberal ocorre a violação da lei pelo Estado, ele incorre em ilegalidade, que tem como efeito a quebra de sua legitimidade e da sua condição de hierárquico superior perante o cidadão, autorizando-o a demandar judicialmente em condições de confronto de pessoa para pessoa num mesmo nível de posições. Tudo isso ocorre porque o desrespeito à lei prejudica o bem comum além do interesse individual. A lesão de direito é, então, o elemento que caracteriza o surgimento do direito subjetivo na esfera pública e que deve ser utilizado para o controle da atividade estatal. ${ }^{28}$ Prevenindo-se de eventuais refutações, Clarice esclarece que não está defendendo o uso de uma arma do direito privado nem do Estado Liberal no ramo público, e sim fazendo uso de um instrumento surgido no advento deste, mas que tem que crescer para acompanhar o andamento do Direito na sociedade que agora se encontra sob os ditames do Estado Social e Democrático de Direito. ${ }^{29}$

Com o exposto, duas celeumas devem ser resolvidas: a) o acesso ao ensino obrigatório e gratuito consiste em prestação do mínimo existencial? b) a satisfação coletiva e a satisfação individual do direito à educação são institutos compatíveis?

No que concerne à alínea “a”, tem-se que, apoderando-se da concepção de mínimo existencial na forma que construiu Ricardo Lobo Torres, é possível concluir que este mínimo não se restringe ao acesso ao ensino fundamental. O referido autor não chega a delimitar precisamente as diferenças entre os direitos fundamentais sociais (mínimo existencial) dos direitos sociais, afirmando que "remanescem alguns problemas intricados à espera do aprofundamento do debate, designadamente no que concerne à clareza na distinção do mínimo existencial (direitos fundamentais sociais) e direitos sociais, da qual dependem a extensão do controle jurisdicional e a integridade do orçamento democrático" ${ }^{30}$ Atribui parâmetros vagos para a identificação do mínimo existencial quando os direitos fundamentais se encaixam nas garantias institucionais de liberdade, na estrutura de serviços públicos essenciais e na organização de estabelecimentos públicos. ${ }^{31}$

A tentativa de Ricardo Lobo Torres de querer poupar os cofres públicos de gastos anti democráticos, afastando a fundamentalidade dos direitos sociais é louvável, no entanto deixa ampla zona obscura quando deixa de delinear o mínimo existencial.

\footnotetext{
${ }^{27}$ DUARTE, loc. cit.

${ }^{28}$ Ibidem. p. 210.

${ }^{29}$ Ibidem. p. 210.

${ }^{30}$ TORRES, Ricardo Lobo. O mínimo existencial, os direitos sociais e os desafios de natureza orçamentária. In: Direitos Fundamentais - orçamento e "reserva do possível”. Organizadores: Ingo Wolfgangg Sarlet, Luciano Benetti Timm. Porto Alegre: Livraria do Advogado Editora, 2008. p. 86.

${ }^{31}$ Ibidem. p. 82.
} 
Essa ideia pode passar a falsa noção de que o direito à educação, direito social declarado no artigo $6^{\circ}$ da $\mathrm{CR} / 88$, não é um direito fundamental.

Verifica-se, então, que o conteúdo do direito à educação, através da fundamentalidade que lhe é conferida pela CR/88, significa muito mais que ter acesso ao ensino fundamental. Envolve o ingresso nos níveis mais básicos de ensino até o ensino superior, se a educação for pensada de forma atrelada à promoção do pleno desenvolvimento da pessoa, o devido preparo para o exercício da cidadania e qualificação para o trabalho. ${ }^{32}$ Ressalvem-se somente as próprias limitações constitucionais, como, por exemplo, a respeito da progressividade da universalização do ensino médio, e a instituição do mérito de cada indivíduo como elemento que permite o acesso ao ensino superior. O que se pretende dizer é que, o fato de o constituinte ter estipulado as referidas restrições, não desobriga o Estado da obrigação de criar e manter escolas de ensino médio e instituições de ensino superior.

Todas as normas constitucionais que se referem à educação são exigíveis e não apenas o acesso ao ensino fundamental, pois conceber o acesso ao ensino obrigatório e gratuito como o mínimo em se tratando da oferta do direito à educação, significa dizer que diante da ausência ou oferta irregular de ensino básico, por exemplo, seria impossível. Não é o caso, porém. Pois, o fato de a Constituição ter designado expressamente que o acesso ao direito fundamental é direito público subjetivo, não retira a subjetividade de outras regras referentes ao direito à educação presentes na CR/88, conforme bem defende Clarice Seixas Duarte. Para a citada autora, inclusive, o fato de o constituinte ter definido o dever constitucional mínimo, que não se confunde com o mínimo existencial, revela o interesse dele em destruir a falsa concepção de que os direitos sociais não geram direitos subjetivos aos inidvíduos. ${ }^{33}$

O direito à educação, assim como qualquer outro direito social, possui como função precípua assegurar o exercício da liberdade fática, pois esta só poderá ser usufruída por quem possuir capacidade para tanto. Significa dizer que a promoção dos direitos fundamentais sociais proporciona o exercício das liberdades fáticas, em sociedades desiguais como a nossa ${ }^{34}$.

Cumpre trazer para o debate considerações sobre a perpectiva jurídico-objetiva dos direitos fundamentais que informa ao Estado deveres de atuação. Como bem demonstra Grimm, o conteúdo jurídico-objetivo dos direitos fundamentais esteve presente em seu nascedouro, não fazendo parte de uma criação nova da doutrina jurídica moderna. Ela ressurge num momento que é interessante para classe média, é verdade, mas sempre esteve presente na substância dos direitos fundamentais. ${ }^{35}$

A elaboração da Constituição de 1988 girou em torno da idealização de um Estado Social e Democrático de Direito, tanto que enumerou objetivos a serem alcançados

32 TAVARES, André Ramos. Direitos Sociais, Fundamentos, Judicialização e Direitos Sociais em Espécie. Coordenadores: Souza Neto, Cláudio Pereira de. Sarmento, Daniel. Rio de Janeiro: Editora Lumen Juris, 2008. p. 777.

${ }^{33}$ DUARTE, op. cit. p. 225.

34 SCAFF, Fernando Facury. Reserva do Possível, Mínimo Existencial e Direitos Humanos. Revista Interesse Público. Porto Alegre: Editora Notadez, jul./ago. 2005, p. 218.

${ }^{35}$ GRIMM, Dieter. Constitucionalismo y derechos fundamentales. Madri: Ed Trotta, 2006. p. 155. 
e nortear toda a atividade de planejamento do Administrador Público, empossado no cargo de representante da sociedade e possuidor do poder de alocar os recursos públicos.

O direito à educação encontra-se no capítulo II da CR/88 reservada aos direitos sociais, pertencente, também, ao Título II, que se refere aos direitos e garantias fundamentais. Nunca é demais dizer que consiste em dever do Estado criar condições de exercício de todos direitos fundamentais. Sendo assim, a carta constitucional elaborou um sistema de proteção aos direitos fundamentais com a criação dos chamados remédios constitucionais, aptos a sanar ameaças ou lesões daqueles. Ocorre que quando se trata do direito à vida, do direito de locomoção, de liberdade de expressão, enfim os constantes no artigo $5^{\circ}$ da CR/88, nunca se questionou a viabilidade em usar os referidos remédios para promover o exercício ou acesso aos direitos ameaçados ou lesados. No entanto, quando se trata dos direitos sociais, a controvérsia se consolida e várias questões são levantadas como obstáculos efetivos à sua concretização.

Que são direitos fundamentais os direitos sociais da mesma forma que os direitos civis e políticos, não há dúvida alguma. Mas por que são levantados tantos óbices em relação aos direitos sociais, esquecidos no momento de aplicação dos direitos de primeira dimensão?

O ponto atingido através da análise feita sobre o fato de que os interesses dominantes é que determinam a ascensão dos direitos leva a crer que as dificuldades impostas à concretização dos direitos sociais é incabível e levantada por razões de cunho político, afastando-se a questão jurídica do problema.

Sabemos que o direito à educação é direito de natureza social cuja implementação se dá por meio de implementação de políticas públicas que atendam às necessidades sociais. Se o Estado estivesse de fato cumprindo com a obrigação de criar condições de real exercício, demandas de judicialização deste direito não teriam razão para existir. Não pelo menos na forma que aparecem, em que se postula a criação de creches, por exemplo, que é a primeira porta de acesso à educação encarada pela pessoa humana.

Em relação à alínea "b”, tem-se que, o fato de a educação ser um direito cujo exercício é promovido através de políticas públicas, ou seja, é um direito que ultrapassa a dimensão individual, não denota que o reconhecimento individual não seja possível.

No que se refere ao direito público subjetivo expressamente consagrado pela Constituição de 1988 como tal, não resta dúvidas de que ao particular foi reservada a possibilidade de ingressar individualmente para requerer a satisfação do referido direito. Diga-se mais: com essa previsão quis o legislador que o Administrador Público se preparasse para a implementação do direito ao acesso ao ensino obrigatório, por meio de planejamento adequado e eficiente. Pois, por razões óbvias, pretende-se que os conflitos não cheguem a existir muito menos cheguem ao Judiciário.

Na pesquisa feita por José Reinaldo de Lima Lopes, acima mencionada, foi identificado que os pedidos individuais em direito à educação foram concedidos com base na fundamentação geral de que é dever do Estado prover os direitos sociais. O citado autor faz referência a uma decisão em que o relator faz a seguinte pergunta: 
"Será que a abertura de uma nova creche ou escola representa valor tão substancial que não possa ser realizado, atendendo a uma garantia tão fundamental como o direito à educação?” Esse questionamento chamou atenção do referido autor, pois o relator não indicou números, não mencionou verbas, ou condições materiais de concretização da sua idéia ao deferir os referidos pedidos. ${ }^{36}$

Ressalte-se que, o que não deve ser esquecido, é que uma decisão isolada, mesmo que sendo numa ação coletiva, não pode prejudicar o todo, não pode causar dano à distribuição do bem comum. Significa dizer que as decisões em direito à educação sempre deverão respeitar o direito de todos sobre o bem comum, e não a vontade de um só grupo social, pois a Constituição traz seu programa político tendo em vista a redução das desigualdades sociais e não a permanência delas. Assim, o parâmetro a ser perseguido é justamente o de verificar se a decisão atende a esse critério constitucional, o que só é verificável isoladamente em cada caso.

Um dos argumentos mais utilizados em desfavor da judicialização da política pública, é que para alguns significa uma judicialização excessiva. ${ }^{37}$ A exigibilidade judicial do direito à educação não pode estar desvinculada das premissas de igualdade e de justiça distributiva.

O direito público subjetivo ao ensino fundamental possui como destinatário “todos". Ou seja, todos aqueles que estiverem com o referido direito ameaçado de lesão ou efetivamente violado pode recorrer ao Poder Judiciário em busca de solução. Do mesmo modo é possível concluir que a intenção do legislador foi também a de que o ensino fundamental atingisse a todos. Todas as pessoas só podem exigir judicialmente o acesso ao ensino obrigatório, porque este direito a elas foi garantido.

Embora a educação seja direito de natureza social e que se insere no âmbito da justiça distributiva, a ser promovido através de políticas públicas atingindo a coletividade, não há como apartar o exercício individual desse direito por cada aluno que tem acesso ao sistema público de ensino.

É certo, pois, que, como direito social, a educação é direito de todos, assim como é certo que há usufruto particular dos serviços ofertados pelo Estado. Pois bem, o fato de a Constituição ter declarado expressamente que acesso ao ensino fundamental é direito público subjetivo não retira a subjetividade dos direitos relativos à educação igualmente presentes no texto constitucional.

Para solucionar estas questões, Clarice Seixas Duarte menciona que

(...) ainda que o Poder Público aplique os percentuais vinculados, isso não significa que a sua obrigação já foi cumprida. Se, não obstante o cumprimento

\footnotetext{
${ }^{36}$ LOPES, José Reinaldo de Lima. Direitos sociais: teoria e prática. São Paulo: Método, 2006. p. 128.

${ }^{37}$ José Reinaldo de Lima Lopes em estudo desenvolvido sobre a judicialização das políticas públicas sobre educação e saúde, relatou que quanto a este, as demandas individuais de requerimentos de medicamentos ou de tratamentos caros em que há uma decisão judicial favorável constitui verdadeira afronta à coletividade que também possui direito à vida e à saúde. Então, nesses casos há o confronto do direito à vida e à saúde de uma pessoa de um lado e de outro, o direito à vida e à saúde da coletividade. Este autor se mostra contrário ao deferimento de demandas individuais em se tratando do direito à saúde. (LOPES, loc. cit.)
} 
da destinação orçamentária das verbas vinculadas, ainda faltar vaga, o indivíduo prejudicado pode exercer sua pretensão individual para exigir a satisfação de seu direito. Nesse caso, tal como ocorre com a ação penal privada, a pretensão individual funciona como complemento da ação pública. Eis aqui um bom exemplo para demonstrar como o fato de a Constituição prever explicitamente que haja verbas para o atendimento de certas demandas não retira dos particulares o direito e a pretensão de exigirem o cumprimento desse princípio constitucional individualmente. Ocorre que, pelo regime geral aplicável aos direitos sociais, é preciso que o façam em um segundo momento. ${ }^{38}$

O que pretende a autora citada é que haja uma espécie de aplicação subsidiária da ideia da ação penal pública, cuja titularidade pertence ao Ministério Público e a aplicação subsidiária da ação penal privada diante da inércia desta instituição. Sendo assim, em primeiro lugar exercita-se o direito de ação por meio do Ministério Público em Ações Civis Públicas e somente num segundo momento a pretensão individual seria proposta em juízo.

Com relação à prioridade absoluta que conferiu às ações coletivas a serem promovidas pelo Ministério Público, a referida autora apresentou um posicionamento adequado à concepção da exigibilidade judicial de todos os direitos sociais, uma vez que são direitos fundamentais.

Compartilha-se da ideia de preferência para o atendimento coletivo do direito à educação, dada a sua natureza e função de distribuição do fundo social comum já comentada, e também sobre a subsidiariedade da ação individual, pois não há como impedir esta possibilidade, e nem existe determinação constitucional nesse sentido. Ao contrário, estabelece a Constituição de 1988 que a ameaça ou lesão a direitos autoriza a busca pelo Judiciário. Quaisquer conclusões em sentido contrário carecem de fundamentação legítima. Sendo o direito à educação um direito fundamental, impedir que demandas individuais sejam propostas de forma individual significa negar acesso ao Judiciário assim como tornar aceitáveis a violação de direitos fundamentais.

$\mathrm{O}$ perigo que pode representar o deferimento de pedidos individuais relativos ao exercício do direito à educação, é que, ao invés de assegurar a efetividade de um direito fundamental, se esteja concedendo privilégios somente a certos grupos, agredindo o princípio da igualdade, conforme a experiência cotidiana dos Tribunais brasileiros, não raras vezes, vêm demonstrando.

Embora não seja tema específico deste trabalho analisar a judicialização do direito à saúde, discutir-se-á a satisfação individual versus a satisfação coletiva do direito à educação, também através de reflexão trazida sobre a implementação daquele direito, pois o raciocínio tende a seguir um roteiro semelhante.

Em relação ao direito à saúde, por exemplo, Vírgílio Afonso da Silva, com estudo realizado no Estado de São Paulo, já mencionado neste trabalho, chegou à conclusão de que as pessoas beneficiadas em ações individuais são as que podem

${ }^{38}$ DUARTE, Clarice Seixas. O Direito Público Subjetivo ao Ensino Fundamental na Constituição de 1988. Faculdade de direito da USP. São Paulo: 2003. p. 227. 
pagar advogado particular, plano de saúde, que moram em lugares nobres. ${ }^{39}$ Enfim, o propósito de atingir as pessoas mais pobres com a implementação de direitos sociais foi completamente desvirtuado para deixar em condições de vantagem indivíduos que de certa forma já estão numa situação privilegiada.

Ora, se o dinheiro público foi empregado para pagar remédios e tratamentos de indivíduos que em sua maioria tinham capacidade material de ter acesso à médicos e advogados particulares, o desfecho que se chega é que essas verbas deixaram de ser aplicadas em políticas públicas que atendem o coletivo para atender uma minoria privilegiada, em razão de uma mudança de interpretação dos direitos fundamentais que só se realizou devido à necessidade de uma classe social que detém certo poder econômico.

O sistema público de saúde é utilizado pela maior parte dos cidadãos, e esta maioria é pobre. ${ }^{40} \mathrm{O}$ resultado desse estudo é bem resumido por Vírgílio Afonso da Silva quando se observa que o título do seu trabalho afirma que o cumprimento dos direitos sociais pela via individual é feita tirando dos pobres para dar aos ricos, trata-se do efeito que denomina de "anti-Robin Hood". ${ }^{41}$ Verificar-se-á, então, se há ocorrência deste efeito no âmbito da satisfação do direito à educação.

O efeito “anti-Robin Hood”, em poucas palavras, ocorre, então, quando recursos são retirados de um potencial investimento coletivo (não necessariamente destinado), e, portanto, para atender a maioria da população que se encontra assolada pelas mazelas causadas pela hipossuficiência financeira, para atender a um indivíduo (ou pequeno grupo de indivíduos em ações isoladas) de classe média para cima. É o que em poucas palavras diz o citado autor: tirar dos pobres para dar aos ricos.

As conclusões atingidas na pesquisa desenvolvida pelo citado autor indicam uma tendência que indica que a busca da judicialização do direito à saúde em ações individuais tem sido empreendida por grupos privilegiados na sociedade. Ocorre o contrário em relação ao direito à educação, pois em que pese o número pequeno de decisões junto ao STF, todas se apresentam em caráter coletivo. É o Ministério Público que vem se destacando na atuação judicial de efetivação do direito à educação através de ações civis públicas tanto no caso Santo André/SP como no caso Queimados/RJ.

Então, que prejuízos pode causar, com relação à concessão de tratamento privilegiado para uns em detrimento de uma coletividade, uma prestação individual do direito à educação, se o que se verifica é que, de um modo geral, são as pessoas pobres que estão recorrendo ao Judiciário por meio da substituição processual exercida pelo Ministério Público? A busca pela judicialização do direito à educação tem se mostrado de forma preponderantemente coletiva e para acesso ao ensino público.

\footnotetext{
${ }^{39}$ SILVA, Virgílio Afonso da. Taking from the poor to give to the rich: the individualistic enforcement of social rights. In: WORLD CONGRESS OF THE INTERNATIONAL ASSOCIATION OF CONSTITUTIONAL LAW, 7, 2007, Atenas. Paper...Atenas, s.n., 2007. p. 15.

${ }^{40}$ Este exemplo não tem pretensões de esgotar discussões sobre o polêmico tema, o objetivo em ter trazido mais uma vez os dados citados foi traçar uma diferença crucial na efetividade do direito à saúde e o direito à educação.

${ }^{41}$ SILVA, Virgílio Afonso da, loc.cit.
} 
Infere-se, então, que, na hipótese de deferimentos de pedidos individuais de satisfação do direito à educação, não ocorre o efeito “anti-Robin Hood”.

Apesar de somente duas decisões terem se destacado no Supremo, tal fato já revela a tendência de que os casos de efetividade do direito à educação que chegam ao STF são de demandas coletivas. E, então, lado a lado tem-se a ideia de aplicabilidade imediata dos direitos sociais, enquanto direitos fundamentais, e a definição constitucional de que o direito fundamental consiste em direito público subjetivo.

Entende-se, portanto, pela prioridade da satisfação coletiva, mas que não há como impor óbices na satisfação individual do direito à educação, pelas razões acima aventadas.

Ainda sobre a defesa dos direitos sociais de um modo geral, muitas alegações são expostas no sentido de restringir a sua efetividade. No entanto, um dos principais argumentos frequentemente levantado, que merece especial destaque, é a reserva do possível que representa a impossibilidade em efetivar tais direitos por falta de recursos. O referido princípio costumeiramente compõe a defesa do Estado quando demandados em ações de judicialização do direito à educação, ocorrendo igualmente nos casos em discussão na resposta ofertada pelo Município de Santo André/SP e Queimados/RJ.

Argumenta-se ainda que, o princípio da eficiência deve ser considerado na implementação de políticas públicas de direito à educação, através da aplicação da lógica de que se alcance o máximo com o menor montante de custos. A esse respeito, há que deixar registradas algumas apreciações.

Embora as críticas feitas em relação ao respeito ao orçamento tenham que ser levadas em consideração, no sentido de que gastos não podem ser realizados sem determinação prévia, e que a falta de considerações do tipo na fundamentação de decisões do STF consiste em ponto a ser enfrentado, o fato de sobrevir uma demanda em satisfação do direito à educação, seja ela coletiva ou, de forma subsidiária e individual, não há verdadeiro impeditivo em não conceder com base nas referidas argumentações. Pois, a lei orçamentária não pode se sobrepor aos direitos fundamentais, oriundos de norma constitucional.

É certo que o manejo com os recursos públicos deve ser tópico a se refletir no trato com a judicialização do direito à educação, pois o que se pretende não é prejudicar nem lesar os direitos fundamentais de quaisquer indivíduos, seja uma coletividade, seja uma pessoa isolada. Pois, a interpretação adequada dos dispositivos e princípios constitucionais é a que indica pela maximização da efetividade dos direitos fundamentais, mesmo que isso implique em pensar em soluções e estratégias de alcance maior de sua aplicabilidade sem olvidar as reais intempéries que possam de fato surgir, como a escassez de recursos. Mas, para a reserva do possível também devem ser alocadas críticas pertinentes.

No tema da judicialização do direito à educação, não se verificou que privilégios estejam sendo concedidos pela Suprema Corte em favor de um grupo minoritário, o que necessariamente exigiria maior aprofundamento da reflexão, como semelhantemente tem ocorrido nas demandas em que se pleiteia tratamento igualitário em função de programa de ações afirmativas. Não é o caso, porém. 
O Estado bem deve se preparar e planejar para promover políticas públicas de atendimento ao direito à educação, para evitar ao máximo a violação deste direito fundamental. Não foi à toa que a Constituição, para auxiliar as atividades do Administrador Público em projetar mecanismo de alcance do exercício real do direito à educação, catalogou minuciosamente como o Estado deve agir. Criando, inclusive, fundos e vinculações orçamentárias específicas para a manutenção e desenvolvimento do ensino.

Como medida saneadora para a falta de verbas já foi sugerido que reservas financeiras devem ser feitas para atingir o fim de cumprimento de decisões judiciais (como frequentemente vem ocorrendo no Rio Grande do Sul) ou até mesmo outros tributos podem ser criados para o referido fim ${ }^{42}$. E acredita-se que, muitas outras soluções que podem ser elaboradas se o propósito for o de maximizar a prestação positiva do direito à educação. O objetivo não é, todavia, o de avaliar a viabilidade de tais sugestões, mas o de apontar um norte para direcionar a reflexão sobre a problemática.

Pois, o que correntemente se vê na doutrina é o embate dos defensores das duas correntes antagônicas, com a preocupação maior em argumentar do que viabilizar concretas resoluções, no sentido de ampliar, sempre, a efetividade dos direitos fundamentais, respeitando e enfrentando as dificuldades financeiras.

O que não pode acontecer, nem se tornar corriqueiro, é aceitar a violação do direito fundamental à educação. Não há dúvida de que as pessoas jurídicas de direito público respondem pelos danos que seus agentes, nessa qualidade, causem a terceiros, conforme determinação do artigo $37, \S 6^{\circ}$, da CR/88.

O Estado não tem outra saída que não seja promover o exercício de direitos fundamentais, podendo arcar com os prejuízos de sua má gestão, seja por meio da judicialização do direito à educação, seja através da responsabilidade Civil do Estado, em caso de ocorrência de dano, comprovados todos os requisitos.

A judicialização do direito à educação envolve, ainda, os instrumentos com que é viabilizada, qual seja, o processo que, observado sob o prisma teleológico tem-se que ele é um instrumento disponibilizado pelo sistema jurídico à sociedade como forma de alcançar a paz social. E enquanto instrumento possui objetivos a serem atingidos através de sua existência. ${ }^{43}$

O processo possui três escopos: os sociais, os políticos e os jurídicos. O escopo social se divide em dois: pacificação social e educação. Através da conscientização dos membros da sociedade dos direitos e deveres, cumpre-se com o escopo social da educação, de forma que as pessoas passem respeitar os liames entre aqueles, e, em último caso, a depositar confiança na alternativa processual que a lei confere para solucionar litígios. O processo deve servir de exemplo para que crie e mantenha a

42 BRITO FILHO, José Cláudio Monteiro de Brito. Direitos Fundamentais Sociais: realização e atuação do Poder Judiciário, in: Revista TRT $8^{\mathrm{a}}$ R, Suplemento Especial Comemorativo. Belém, v. 41, n. 81, Jul./Dez. 2008, p. 85.

43 DINAMARCO, Cândido Rangel. A Instrumentalidade do Processo. São Paulo: Malheiros Editores, 2005, p. 181. 
esperança em resolver os litígios através do Poder Judiciário. Os escopos políticos do processo são a tentativa do Estado em concretizar os objetivos políticos que se encontram embutidos nas leis. Tais escopos são: estabilidade das instituições políticas e o exercício da cidadania. Este exercício engloba a participação política do cidadão, para acompanhar as atividades estatais, como meio de fiscalização e participação nos destinos do Estado. É por isso que o ordenamento jurídico disponibiliza ações judiciais para a defesa de direitos com vistas a possíveis atitudes arbitrárias dos agentes estatais, como: mandado de segurança, ação popular, ação civil pública, entre outros. O escopo jurídico, em consonância com teoria dualista, é a atuação da vontade concreta da lei. ${ }^{44}$

A ideia da instrumentalidade do processo se traduz na ótica que enxerga este como instrumento apto a alcançar os escopos sociais, políticos e jurídicos já mencionados. Desse modo, processo efetivo é aquele que atinge todos os escopos do processo, sem deixar quaisquer rastros de descontentamento humano, através de decisões judiciais pautadas no valor justiça.

Com efeito, o processo na judicialização do direito à educação pode ser encarado como forma de educação do Poder Público no trato com o referido direito e na gestão dos recursos públicos, como modo de atingir o escopo social, se mostrando, neste ponto de vista, uma providência indispensável. Os escopos políticos, de participação do sujeito democrático na administração da coisa pública, também são alcançados, assim como os escopos jurídicos que envolvem a vontade, o conteúdo, da lei.

Não é o ideal que o direito à educação seja efetivado com a judicialização, mas esta se torna medida cabível diante de uma lesão, sendo uma providência excepcional, e quando individual, de caráter supletivo.

Os mandamentos constitucionais através da imposição de deveres de atuação ao Estado em relação ao direito à educação, devem ser encarados como de execução por meio de atos vinculados, onde a discricionariedade, em relação à determinação feita nos artigos definidos ao tratamento da matéria, não tem espaço para incidência. E onde, argumentos da reserva do possível não pode lograr êxito, pois faz parte das incumbências estatais observar as normas constitucionais antes de elaborar políticas públicas.

A experiência de cidadão comum mostra que o trato do Poder Público com os recursos públicos não tem sido dos melhores. Frequentemente escândalos de corrupção e desvio de verba são noticiados pelos meios de comunicação, assim como informações a respeito de gastos excessivos com interesses particulares, alheios ao interesse público. $^{45}$ Por estas razões que se torna perigoso defender a bandeira da reserva do

${ }^{44}$ Ibidem. p. 194 et seq.

45 Pesquisa realizada pela organização não-governamental independente e autônoma denominada Transparência Brasil constatou que o Congresso brasileiro é o mais caro para a população em comparação com outros países pesquisados, quais sejam: Alemanha, Argentina, Canadá, Chile, Espanha, França, Grã-Bretanha, Itália, México e Portugal, apenas perdendo para os Estados Unidos. O estudo revela, ainda, que cada deputado federal apresentou custo de 6,6 milhões de reais, sendo o total de 513, enquanto que cada senador, o valor de 33,1 milhões de reais por ano, sendo o total de 81, no ano referido. O inteiro teor da pesquisa encontra-se no site www.transparenciabrasil.org.br. 
possível tão somente para restringir a efetividade dos direitos fundamentais, e sem a indicação de um direcionamento que viabilize o pleno exercício deles.

Como exemplo de medida a auxiliar o custeio dos direitos sociais, foi editada a Contribuição provisória sobre a movimentação ou transmissão de valores e de créditos e direitos de natureza financeira, a CPMF, de 1997 a $2007^{46}$. A destinação da arrecadação era para a saúde pública, previdência social e o fundo de combate e erradicação da pobreza, com a superveniência da Emenda Constitucional no 21 .

Os objetivos da tributação provisória acabaram sendo perdidos pelo Congresso Nacional, que passou a autorizar a desvinculação das receitas da União que incidia sobre a CPMF. Ou seja, um tributo criado para complementar a implementação de direitos sociais foi de forma flagrantemente inconstitucional desvirtuado para fins outros, cuja prioridade sempre será questionável em confronto com a promoção de direitos fundamentais. A prorrogação da CPMF até 2011 foi rejeitada pelo Senado Federal em votação ocorrida em 2007, embora a desvinculação das receitas da União ocorra ainda.

São posturas inaceitáveis do Poder Público, dentre muitos outros exemplos, que indicam o descaso com a efetividade dos direitos fundamentais, que expressam como o manejo dos recursos público é feito e que merecem correção.

A participação do Poder Judiciário, em que pese as suas restrições técnicas que não se quer sejam ignoradas, também é de transformador da realidade, pois seu trabalho em demandas de judicialização de políticas públicas será o de por meio do controle de constitucionalidade que lhe cabe realizar, no cumprimento de suas atribuições enquanto um dos poderes do Estado, evitando injustiças e promovendo a igualdade material nos moldes que preconizam as normas educacionais presentes na Constituição de 1988.

\section{CONSIDERAÇÕES FINAIS}

O primeiro apontamento a ser considerado ao final deste artigo é que o papel a ser desempenhado pelo Estado na concretização do direito à educação é fundamental para que se alcancem os objetivos traçados pela Constituição no artigo $3^{\circ}$, e incisos I, II, III e IV. Conhecer tais normas consiste, então, no primeiro passo em busca da efetivação do direito à educação. O segundo passo é a busca por um parâmetro hermenêutico que melhor se ajuste à lógica constitucional em instituir objetivos e de declarar a República Federativa do Brasil, um Estado Democrático e Social de Direito.

O pleno desenvolvimento da pessoa, o seu preparo para o exercício da cidadania e a qualificação do trabalho por meio da educação, conferem ao indivíduo a condição de sujeitos democráticos, atuantes na participação política do país, fiscalizadores e controladores das atividades empreendidas pelo Estado. Fazem com que se vejam na representação política que aderem nos pleitos eleitorais, isto é, que identifiquem no representante uma vontade que é sua, estando hábil a corrigir distorções quando existirem.

\footnotetext{
${ }^{46}$ A Lei 9.311/96 instituiu a CPMF.
} 
O direito à educação, enquanto componente do grupo de direitos sociais, é alvo de argumentações que pretendem restringir a sua efetividade, esquecidos quando se tratam dos direitos civis e políticos. O início da ascensão dos direitos sociais e o processo de judicialização da política pública no Brasil encontram-se vinculados aos interesses da classe dominante, no entanto o que se pretendeu no presente artigo foi a defesa do direito à educação de forma imparcial, considerando-o tão somente direito fundamental que clama por exequibilidade.

O princípio da universalidade do acesso ao ensino, embora não esteja expressamente previsto na Constituição de 1988, apenas aparecendo na designação “todos” no caput do artigo 205, encontra-se presente em diversos artigos. O referido princípio deve ser utilizado para compreender o elenco de garantias a serem fornecidas pelo Estado na implementação do direito à educação. Somente desse modo é possível entender o objetivo do legislador constituinte de pretender que o direito à educação esteja ao alcance de todos, sem quaisquer distinções.

Para a solidificação do Estado Social e Democrático de Direito, o exercício do direito à educação se mostra um pressuposto imprescindível e que faz parte do usufruto de outros direitos. Com a educação, exercita-se a liberdade de expressão, de pensamento, de ir e vir, toma-se ciência do direito de ação, enfim, são incontáveis os benefícios.

As políticas públicas funcionam como instrumento e, ao mesmo tempo, se refletem em forma de atividade do governo. Elaboradas pelos Poderes do Estado, Legislativo e Executivo, são padrões normativos que se corporificam em leis, possuem objetivos delineados e tempo de existência delimitado. Uma vez consideradas instrumentos por meio do qual o Estado implementa direitos fundamentais e que se fundamentam em normas constitucionais, refletem a soberania popular, autorizando a comunidade política a exercer controle e fiscalização delas.

O Poder Judiciário deve, então, exercer controle de constitucionalidade das políticas públicas de promoção do direito à educação implementadas pelo Poder Executivo e normatizadas pelo Poder Legislativo por meio do exercício de suas atribuições. Pois, ao Estado não cabe outro tipo de medida que não seja pensar, prioritariamente, na efetividade dos direitos fundamentais. A atuação do Poder Judiciário não será arbitrária e tampouco usurpará as fronteiras impostas pelo princípio de separação dos poderes. Será pautada nos princípios e dispositivos constitucionais, consistindo em verdadeiro exercício de suas atribuições designadas pela carta magna.

Então, a análise do direito à educação e a defesa por sua judicialização, pressupõe uma compreensão correta dos direitos fundamentais, normas que justifica a organização e a estrutura de todo o ordenamento jurídico, bem como justifica a própria existência do Estado, postulados que fundamentam as conclusões construídas no presente estudo.

A proteção dos direitos humanos se relaciona com o modelo de Estado e com a postura política dos juízes no momento de proferir uma decisão, pois as decisões judiciais refletem os conflitos de toda ordem existentes na sociedade, sejam políticos, econômicos ou sociais. O Estado Liberal prioriza os direitos de primeira dimensão 
(propriedade privada, liberdades públicas e outros) e funciona sem a preocupação imediata em superar o desequilíbrio sócio-econômico, enquanto que o Estado Social dá preferência aos direitos de segunda dimensão (saúde, educação, moradia e outros) e se compromete com atuação corretiva, conforme os postulados da justiça distributiva que o Estado Social e Democrático de Direito se propõe a seguir. ${ }^{47}$

No Estado Liberal, é suficiente apenas fazer controle de legalidade dos atos estatais, uma vez que a lei é o parâmetro do Estado de Direito, e toda invasão de liberdade tem alicerce nela. No entanto, o contrário ocorre num Estado Social e Democrático de Direito, em que prestações positivas de natureza transformadora devem ser efetivadas como forma de atender, por meio de políticas públicas, às necessidades de grupos sociais vulneráveis. ${ }^{48}$ É que os direitos civis e políticos, base do Estado Liberal Clássico, encontram-se num patamar tal que qualquer cerceamento ilegítimo na liberdade autoriza que o poder de exigir o cumprimento desses direitos entre em ação no mundo jurídico, e ao Estado seja ordenada uma prestação negativa: que deixe de intervir, e é exatamente a mesma postura que se pretende que aconteça no Estado Social e Democrático de Direito, superando-se obsoletas concepções a respeito da efetividade dos direitos sociais. ${ }^{49}$

Sendo a República Federativa do Brasil um Estado Social e Democrático de Direito, carrega consigo a pretensão em modificar a estrutura sócio-econômica do país, e isto só se torna viável por meio de políticas públicas que sejam criadas para suportar as carências sociais, conforme já afirmado.

O Estado deve igualmente ser forçado a implementar medidas positivas de proteção aos direitos sociais em casos de omissão ou prestação insuficiente, além do cumprimento das leis. ${ }^{50}$ A concepção de justiça distributiva foi atrelada pela Constituição de 1988 como sustento para suportar as atividades estatais, caso contrário não seria objetivo constitucionalmente delineado a erradicação da pobreza, da marginalização, e a redução das desigualdades sociais e regionais. ${ }^{51}$

A interpretação que se mostra mais adequada para a efetividade do direito à educação, é a que conclui pela possibilidade de consertar os erros da Administração Pública quando esta deixar de tomar medidas (ou sendo estas insuficientes) que visem à repartição dos bens da coletividade.

$\mathrm{O}$ argumento de que questões políticas devem ser afastadas do controle judicial vem sendo superada pela doutrina, embora setores mais tradicionais continuem rígidos nesse aspecto. É irrefutável a constitucionalidade que as políticas públicas assumem uma vez que são elaboradas para cumprir objetivos configurados na Constituição e o exercício de direitos fundamentais.

Ademais, a normatividade das políticas públicas faz parte do seu conteúdo, uma

${ }^{47}$ POMPEU, Gina Vidal Marcílio. Direito à educação: controle social e exigibilidade judicial. Rio São Paulo - Fortaleza: ABC Editora, 2005. p. 220.

${ }^{48}$ DUARTE, Clarice Seixas. O Direito Público Subjetivo ao Ensino Fundamental na Constituição de 1988. Faculdade de direito da USP. São Paulo: 2003. p. 207.

${ }^{49}$ Ibidem. p. 214.

${ }^{50}$ Ibidem. p. 221.

${ }^{51}$ Vide artigo $3^{\circ}$, inciso III, da CR/88. 
vez que são elaboradas pelos representantes eleitos. Significa dizer que são feitas pela própria comunidade via indireta, o que autoriza o controle e fiscalização por parte desta. Não só isso. As políticas públicas são reflexos da soberania popular.

O debate acerca da possibilidade de o Poder Judiciário ter competência de apreciar questões ditas políticas surgiu em função de uma clássica distinção feita pela tradição liberal: a de que questões políticas não são jurídicas. Atribui-se à justiça comutativa as questões de direito e à justiça distributiva as questões políticas. ${ }^{52}$

Ainda que as políticas públicas sejam consideradas como conjunto de atos e normas que expressam as opções políticas do governo, essas escolhas devem estar perfeitamente ajustadas com as normas constitucionais, sob pena de se incorrer em inconstitucionalidade. As políticas públicas funcionam apenas como materialização dos comandos constitucionais.

É por isso que o fato de a lei se transformar num recurso para executar os planos de governo no Estado Social e Democrático de Direito, não consiste em óbice para o controle das políticas públicas nem torna nebulosa essa atividade fiscalizatória. ${ }^{53}$ Ao contrário, legitima a participação da comunidade política e justifica a possibilidade de acompanhamento das atividades estatais.

O juízo de constitucionalidade deve ser assumido pelo elaborador das políticas no ato de criação delas, incidindo sobre as leis e atos normativos que as executam (artigo 102, I, “a”, CR/88), bem como por meio da análise dos efeitos dos instrumentos selecionados para a sua implementação. ${ }^{54}$

A ausência ou escassez de arcabouço institucional que ofereça condições para que a sociedade civil providencie atividade fiscalizatória própria sobre as políticas públicas do mesmo modo não serve como desestímulo ao controle judicial. A responsabilidade da sociedade não anula a incumbência do Poder Judiciário em fiscalizar a constitucionalidade de leis e atos normativos, pelo contrário, essa totalidade de circunstâncias sociais acaba incentivando o controle, mostrando-nos o caráter de urgência com que ele se reveste, pois revela como a deficiência da educação prejudica o desenvolvimento da democracia e o exercício da cidadania, e, conseqüentemente, o pleno gozo dos direitos fundamentais.

A possível sobrecarga do Poder Judiciário se dá em virtude da crise da democracia, anunciada pertinentemente por Eduardo Appio $^{55}$, e está completamente relacionada

52 Sobre o assunto, ressalte-se o posicionamento de José Reinaldo de Lima Lopes que vislumbra que a demarcação entre o jurídico e o político fica comprometida quando o assunto é direito constitucional. Para o autor, litígios que envolvem a referida matéria fazem fundir o político e o jurídico. (LOPES, José Reinaldo de Lima. Direitos sociais: teoria e prática. São Paulo: Método, 2006. p. 124).

${ }^{53}$ Marília Lourido do Santos aduz que as políticas públicas se encaixam num setor intermediário entre a lei e o ato normativo, e que a necessidade de aprovar leis provenientes do Executivo para implementação de políticas pública origina grande demanda por legislação, circunstância que a autora considera como considerável dificuldade para o exercício do controle social e judicial das políticas públicas. (SANTOS, Marília Lourido dos. Interpretação Constitucional no controle judicial das políticas públicas. Porto Alegre: Sérgio Antônio Fabris, 2006. p. 89)

${ }^{54}$ COMPARATO, Fábio Konder. Ensaio sobre o Juízo de Constitucionalidade de Políticas Públicas. São Paulo: Revista dos Tribunais, vol. 737, março de 1997. p. 20.

${ }^{55}$ APPIO, Eduardo. Controle Judicial das Políticas Públicas no Brasil. Curitiba: Juruá, 2005. p. 138. 
com a deficiência do exercício da cidadania que é promovido pela educação, reitere-se. E esse sobrepeso não desautoriza a atuação judicial e nem deve servir para desvirtuar as atenções, simplesmente expressa o caos social.

À medida que os outros setores da sociedade forem se mobilizando para efetivamente cobrar dos governos o cumprimento da Constituição e das legislações por vias administrativas, o Poder Judiciário esvaziar-se-á. Ocorre que isto só será possível quando os indivíduos tiverem acesso à educação, e se por enquanto o caminho mais viável para ter possibilidade de usufruto da educação diante de uma medida inconstitucional do governo em manter pessoas fora da escola tem sido recorrer aos Tribunais, então que eles cumpram seu papel magnamente designado em não permitir que ocorram ameaças nem lesões à direitos fundamentais.

As prestações positivas que concretizam o direito à educação se expressam por meio de políticas públicas, que por sua vez abrangem a concretização de todos os direitos fundamentais, considerando-se o liame e a dependência recíproca que há entre os direitos civis e políticos e os direitos sociais já analisados. Assim, a normatividade dos direitos fundamentais encontra estreita relação com as políticas públicas cujo fundamento é igualmente oriundo da Constituição de 1988, o que faz deduzir que o controle a ser exercido é de cunho constitucional. ${ }^{56}$

No controle judicial das políticas públicas educacionais deve-se considerar que um dos objetivos determinados pela Constituição é a redução das desigualdades sociais, óbvio mencionar que os grupos mais vulneráveis da sociedade devem ter especial atenção na elaboração de políticas públicas.

A própria carta constitucional quando se refere em seu artigo 205 ao direito à educação como direito de todos deixa evidente sua universalidade. Também deixa claro que a efetivação desse direito será progressiva, no sentido de propiciar aumento do acesso ao ensino para que seja exercido de forma equânime. O que não significa que o Poder Público possa deixar de realizar políticas públicas.

Nesse sentido, o Comentário Geral $\mathrm{n}^{0}$ 3, de 1990, do Comitê de Direitos Econômicos, Sociais e Culturais da ONU ${ }^{57}$, sobre o Pacto Internacional de Direitos Econômicos, Culturais e Sociais, sugere que a progressividade apenas guarda relação com as dificuldades estruturais que cada Estado encontra para a implementação desse direito. Trata-se de uma interpretação oficial que tem como objetivo fazer permanecer a ideia de que a realização do direito à educação não deve perder seu conteúdo obrigatório.

Tudo isso porque consiste em ingenuidade desconsiderar que os objetivos da Constituição e seu programa político de implementação de direitos é projeto a ser executado paulatinamente, cujos resultados são a longo prazo. Para isso, necessário se torna estabelecer prioridades para o atendimento do direito à educação, bem como respeitar as vinculações constitucionais a respeito do dinheiro público destinado à educação.

\footnotetext{
${ }^{56}$ SANTOS, op. cit. p. 87.

${ }^{57}$ Vide General Comment n. 3, UN doc. E/1991/23, Comentário Geral n. 3, de 1990, do Comitê de Direitos Econômicos, Sociais e Culturais da ONU que encontra-se disponível no site: http://www.dhnet.org.br, traduzido por Adriana carneiro Monteiro. Acessado em: 25 abr. 2008.
} 


\section{REFERÊNCIAS}

ABRAMOVICH, Victor; COURTIS, Christian. Linhas de trabalho em direitos econômicos, sociais e culturais: instrumentos e aliados. Sur. n. 2, 2005, p. 189-219.

. Los derechos sociales como derechos exigibiles. Madrid: Trotta, 2002.

AMARAL, Gustavo. Direito, escassez \& escolha: em busca de critérios Jurídicos para lidar com a escassez de recursos e as decisões trágicas. Rio de Janeiro: Renovar, 2001

APPIO, Eduardo. Controle Judicial das Políticas Públicas no Brasil. Curitiba: Juruá, 2005.

ATIENZA, Manuel. El sentido del derecho. Barcelona: Ariel, 2004. p. 251-271.

BONAVIDES, Paulo. Teoria do Estado. 6. ed. rev. e ampl. São Paulo: Malheiros Editores, 2007.

BRITO FILHO, José Cláudio Monteiro de. Direitos Fundamentais Sociais: realização e atuação do Poder Judiciário. Revista TRT $8^{a}$ Região - Suplemento Especial Comemorativo. Belém, v. 41, n. 81, Jul./Dez. 2008, p. 77-87.

CANOTILHO, José Joaquim Gomes. Direito Constitucional. 5. ed. Coimbra: Livraria Almedina, 1991.

COMPARATO, Fábio Konder. Ensaio sobre o Juízo de Constitucionalidade de Políticas Públicas. São Paulo: Revista dos Tribunais, vol. 737, mar. 1997.

DIAS, Jean Carlos. O Controle Judicial de Políticas Públicas. São Paulo: Método, 2007.

DUARTE, Clarice Seixas. A Educação como um direito fundamental de natureza social. Educ. Soc. Campinas, v. 28, n. 100 - Especial, p. 691-713, out. 2007. Disponível em http://www.cedes.unicamp.br, Acesso em: 22 jan. 2009.

. O Direito Público Subjetivo ao Ensino Fundamental na Constituição de 1988. São Paulo: Faculdade de Direito da USP: 2003.

ENGISCH, Karl. Introdução ao Pensamento Jurídico. Lisboa: Fundação Calouste Gulbenkian, 1996.

FERREIRA, Fernando Galvão de Andréa. Democracia e educação. In: GARCIA, Emerson (Org.). A Efetividade dos Direitos Sociais. Rio de Janeiro: Lúmen Júris, 2004. p. 127-147.

FRANÇA, Júnia Lessa et al. Manual para Normalização de Publicações Técnico-Científicas. Belo Horizonte: UFMG, 2007.

FREIRE, Paulo. Pedagogia da Autonomia - saberes necessário à prática educativa. São Paulo: Paz e Terra, 1996.

FRISCHEISEN, Luíza Cristina Fonseca. Políticas Públicas, a responsabilidade do Administrador e o Ministério Público. São Paulo: Max Limonad, 2000.

GARCIA, Emerson. O direito à educação e suas perspectivas de efetividade in: GARCIA, Emerson (Org.). A efetividade dos direitos sociais. Rio de Janeiro: Lúmen Júris, 2004. p. 149-198. GRIMM, Dieter. Constitucionalismo y derechos fundamentales. Madri: Trotta, 2006.

LIMA, Isabela Bentes de. Desvinculação de receitas da União e escassez: a desafetação de recursos direcionados aos direitos sociais. In: Âmbito Jurídico, Rio Grande/RS, 50, 29.02.2008 Disponível em:

http://www.ambitojuridico.com.br/site/index.php?n_link=revista_artigos_leitura\&artigo_id=4516. Acesso em 14 abr. 2009.

LIMA, Maria Cristina de Brito de. A Educação como Direito Fundamental. Rio de Janeiro: Lumen Juris, 2003.

LOPES, José Reinaldo de Lima. Direitos Sociais - teoria e prática. São Paulo: Método, 2006.

DiReITOS FundamentaIS E J JustiçA N' 13 - OUt./DEZ. 2010 
MALISKA, Marcos Augusto. O Direito à Educação e a Constituição. Porto Alegre: Sergio Antonio Fabris Editor, 2001.

MIRANDA, Jorge. Manual de Direito Constitucional. Tomo III. p. 435.

MÜLLER, Mary Stela; CORNELSEN, Jule Mary. Normas e Padrões para Teses, Dissertações e Monografias. Londrina: Eduel, 2007.

PEREZ LUNÕ, Antonio E. Derechos humanos, Estado de Derecho y Constitucion. 5. ed. Madrid: Tecnos, 1995, p. 21-51.

PIOVESAN, Flávia. Direitos Humanos e o Direito Constitucional Internacional. São Paulo: Saraiva, 2007.

. Temas de Direitos Humanos. São Paulo: Max Limonad, 2003.

POMPEU, Gina Vidal Marcílio. Direito à educação: controle social e exigibilidade judicial. Rio de Janeiro: ABC Editora, 2005.

SANTOS, Marília Louridos dos. Interpretação Constitucional no Controle Judicial das Políticas Públicas. Porto Alegre: Sérgio Antônio Fabris, 2006.

SARLET, Ingo Wolfgang. A Eficácia dos Direitos Fundamentais. 4. ed. rev. atual e ampl. Porto Alegre: Livraria do Advogado, 2004.

SARLET, Ingo Wolfgang; TIMM, Luciano Benneti (organizadores). Direitos Fundamentais orçamento e "reserva do possível”. Porto Alegre: Livraria do Advogado, 2008.

SCAFF, Fernando Facury. Reserva do Possível, Mínimo Existencial e Direitos Humanos. Revista Interesse Público. Porto Alegre: Editora Notadez, jul./ago. 2005.

As contribuições sociais e o princípio da afetação. Revista Dialética de Direito Tributário, n. 98, nov. 2003. p. 44-62.

A Desvinculação das Receitas da União (DRU) e a Supremacia da Constituição. In: MAUÉS, Antônio Gomes Moreira; SCAFF, Fernando Facury. Justiça Constitucional e Tributação. São Paulo: Dialética, 2005, p. 96-113.

SCHWARTZMAN, Simon. Educação e pobreza no Brasil in: Cadernos Adenauer VII, n ${ }^{\circ} 2$ Educação e pobreza na América Latina. Rio de Janeiro: Fundação Konrad Adenauer, 2006.

SEN, Amartya. Desenvolvimento como Liberdade. São Paulo: Companhia das Letras, 2000. p. 17-108.

SILVA, Virgílio Afonso da. Taking from the Poor to give to the Rich: the individualistic enforcement of social rights. In: WORLD CONGRESS OF THE INTERNATIONAL ASSOCIATION OF CONSTITUTIONAL LAW, 7, 2007, Atenas. Paper... Atenas, s.n., 2007.

SOUZA NETO, Cláudio; SARMENTO, Daniel. (Coordenadores). Direitos Sociais - Fundamentos, Judicialização e Direitos Sociais em espécie. Rio de Janeiro: Lumen Juris, 2008.

STRECK, Lenio Luiz; MORAIS, José Luis Bolzan. Ciência Política e Teoria Geral do Estado. Porto Alegre: Livraria do Advogado, 2000.

STRECK, Lênio. Jurisdição Constitucional e Hermenêutica. 2. ed. Rio de Janeiro: Forense, 2004.

TORRES, Ricardo Lobo. (Org.). Os Direitos Humanos e a Tributação: imunidades e isonomia. Rio de Janeiro: Renovar, 1995.

VIEIRA, Oscar Vilhena. Direitos Fundamentais: uma leitura da jurisprudência do STF. São Paulo: Malheiros, 2006. 